\title{
DAVID KASER
}

\section{A Century of Academic Librarianship, As Reflected in Its Literature}

\begin{abstract}
A A past from several different vantage points. It can comb the minutes of its corporate actions; it can piece together the lives of its great practitioners; it can reconstruct such archaeological remains as its older buildings, equipment, forms, and other artifacts. These and other kinds of study will all contribute usefully to a better perspective against which the profession can judge the decisions it faces, can separate the transient occurrences of the moment from the more chronic and permanent conditions deserving higher priority attention, and can improve the wisdom of its future actions through an understanding of what has been tried before.
\end{abstract}

This essay will attempt to review the last century of academic librarianship as it is reflected in its literature. It will note not only what was written, but it will also try to determine why it was written, as well as to speculate upon the reasons for its being written when it was written. It will view the literature neither comprehensively nor statistically, although both of those approaches deserve also to be taken, but rather based upon a very limited selection of its highest peaks and most notable landmarks. Any such selection must be highly subjective, and although many of the works discussed herein will doubtless enjoy the concurrence of most American library historians, others will clearly be seen as personal. Nonetheless, it is hoped that the selection will be adequate to permit the identification of some trends and influences and the positing of some useful generalizations about the development of the profession of academic librarianship.

\section{The Beginnings}

Any surveyor of the literature of librarianship during the two decades following 1876 must be struck by how very little was written in the period which concerned specifically academic libraries. That heavy compendium produced in 1876 by the U.S. Bureau of Education, entitled Public Libraries in the United States, contained only two essays about college and university libraries per se. Yet many, perhaps most, of the other thirty-six pieces, while general in subject, were written by academic librarians, making it as clear to the reader that these founders of the profession had their minds so affixed to the commonalities of concern among all libraries that they were unable yet to ponder the uniquenesses of the several kinds of libraries.

The periodical literature of the period supports this perception. Although the October 1877 issue of Library Journal was a "college number," the periodical press outside of that single issue 
carried fewer than a half-dozen articles on college and university libraries before the mid-1880s. A growing sense of identity among academic librarians marked the last decade of the nineteenth century, however. Not only did its literature grow heavier during that period, but there were other manifestations as well. A College Library Section of ALA was formed in 1890, and in 1896 Maude Wheeler Carman presented a thesis to the Armour Institute of Technology entitled "The College Library; How It Differs from a Public Library."

Academic librarianship's lack of selfawareness during the first quarter of the period under review here is demonstrated nowhere more than in the bibliography of the subject. The first attempt publicly to "bibliographize" academic librarianship was apparently not made until the turn of the century, when in 1899 Hugh Williams of the Library of Congress produced his fifty-five-page document entitled College Libraries in the United States; Contributions toward a Bibliography. Published as number 19 in the "Bibliographic Bulletin" series of the New York State Library, this publication established that institution as the geographical center of academic library bibliography for some three and a half decades thereafter.

Bibliographical coverage of the literature for the period 1899 to 1926 became available in the latter year when the Bibliography of American College Library Administration was issued also by the New York State Library as its "Bibliographic Bulletin" number 77 . This new publication was greatly larger than its predecessor and contained some 600 titles. Practically no books had been written during the period, however, and fully one-fourth of the entries were unidimensional descriptions of collections, processes, or circumstances within individual libraries. There were no research investigations or empirical analy- ses to be reported; that kind of scholarly writing had not yet come into the field.

Nor had any journals yet come into being which were addressed primarily to college and university libraries. That was still almost fifteen years ahead. Most of the articles published before 1925 had appeared, predictably perhaps, in Library Journal. The ALA Bulletin had published several, as had also Public Libraries, which later became $L i$ braries. School and Society and other nonlibrary journals, were also represented by a number of items. Many of the works cited were not from periodicals at all but from annual reports and handbooks of local libraries; proceedings of workshops and dedicatory ceremonies; addresses; and other similar documents.

The subject matter of the items listed in this quarter-century bibliography ranged pretty evenly over the full spectrum of the academic library concerns of that or any other period. Aspects of finance and budgeting were well represented, as were articles on the several library processes, such as acquisition, circulation, cataloging, and reference. Many articles discussed personnel, including concerns for training, qualifications, rank, vacations, salaries, and the like. There were some papers on buildings and equipment (largely descriptive), the role of library faculty committees, and such public relations activities as mounting exhibits, publishing, and the preparation of reports. Surprisingly heavy was the literature dealing with instruction in use of the college library, extending to fully thirty-eight entries, or almost 7 percent of the total. Collection development, book selection, and public services, on the other hand, were relatively lightly treated.

The names of the most prolific authors during this period were predictably different from those of the previous. Although an occasional piece still 
turned up by such original nineteenthcentury worthies as Charles Ammi Cutter and Melvil Dewey, these years reflected the work of a whole new army of library giants. William Warner Bishop of the University of Michigan was everywhere, publishing well over 100 books, articles, and reviews in this quarter-century alone. Here also was the ubiquitous Louis Round Wilson. Oberlin's Azariah S. Root wrote prolifically, as did Princeton's E. C. Richardson, Cornell's Willard Austen, F. K. W. Drury then of Brown, and James Ingersoll Wyer of the New York State Library. Women, notably silent before the turn of the century, began to make their presence known in print, and writings appeared over the names of Columbia's Isadore Gilbert Mudge and Margaret Hutchins and Minnie Earl Sears, then of the New York Public Library. By the end of the period still another generation of great librarians was beginning to raise its voice also, and there were pieces by Keyes D. Metcalf, Charles B. Shaw, and Frank K. Walters.

By the end of the first quarter of the twentieth century, the literature of academic librarianship had become very substantial, and even the simple task of listing it regularly had become a chore of some magnitude. Dorothy Plum continued the work, however, and all-told issued four supplements to the Albany bibliographies covering the next seven years. The first three supplements appeared one each in the three Yearbooks (1929, 1930, and 1931) of ALA's College and Reference Section, and the fourth, for 1931-1933, was published in the latter year by the Vassar College Library. The separate listing of the literature of academic libraries largely ended there, however. H. G. T. Cannon's comprehensive Bibliography of Library Economy 1876-1920, had appeared in 1927, and this was brought up to 1934 when ALA's Junior Members Round Table produced Library Literature for the next decade. The latter monument, of course, continues today under the auspices of the H. W. Wilson Company, eliminating the need for special coverage in the academic field. Merging academic library listings into those of other library literature, however, rendered them thereafter difficult, if possible at all, to review at a glance, diminished the profile of the leading writers in the field, and ended an important era in academic librarianship.

\section{The Development of Textbooks}

During the first third of the century under discussion here, there was no single text to which a reader could go to gain an overall impression of the scope and work of academic librarianship. When the first effort was made to repair this deficiency, moreover, it was a modest effort indeed, containing only eighteen pages. Written by James Ingersoll Wyer, The College and University Library comprised number 4 in ALA's thirty-two-part "Manual of Library Economy." Attempting to describe best contemporary practice, this little handbook contained brief essays on the functions of college and university libraries, buildings, governance, the librarian and other staff, finances, departmental libraries, and the administration of library operations. This slender pamphlet remained the sole textbook in the field for fully twenty-five years, and reappeared in revision in 1921 and 1928.

A very difficult problem standing in the way of proper textbook development not only for college and university librarians but for the rest of librarianship as well in those early days was not to determine just what constituted "best practice," but indeed "practice" at all. Most discussions of practice in the literature had been either speculative or had described methods which were as yet untried; others, as was mentioned earlier, concerned procedures within a single library. Librarians could augment 
this kind of information only by visiting other libraries or talking with other librarians. It was at best a slow and tedious business.

By the time of World War I, however, the profession had concluded that such ignorance about itself was no longer tolerable. In 1919 ALA President William Warner Bishop appointed a "Committee of Five" to conduct a survey of the entire field of library service. With a grant from the Carnegie Corporation of New York, this group sent questionnaires to more than 3,000 libraries across the nation in an attempt to determine just what and how things were being done in American libraries. Some 261 replies were received from academic libraries, and these, together with responses from other libraries, were used in the preparation of ALA's four-volume Survey of Libraries in the United States which appeared in 1926.

The survey by today's standards was amateurish and unsophisticated in both conceptualization and analysis. The report contained some simple statistics and much description of actual practice in the college and university libraries of the land. Under "Administration" there were data on faculty library committees; the number, size, and administration of departmental and seminar collections; and the organizational structure of the library. There were financial data on such matters as the percentage of the budget spent for materials, perstudent expenditure for books and staff, ratio of library to institutional expenditure, and the apportionment of funds. Information was reported on personnel practices, including appointments and promotions, education of librarians, salaries, working hours, and staff welfare. And data were given on hours of opening, library fees, overdue fines, access to stacks, nonbook materials, and other public service matters. The technical services were represented by information on cataloging, classification, ac- counting, and binding practices.

For the first time in its history, academic librarianship was possessed of a body of hard data about itself. Some of it was inaccurate, some was incomplete, some was unanalyzed, some was not what was truly needed. Nonetheless, the potential utility of such data was obvious. Improved in quality and quantity, it was for the first time recognized that such data could lead not only to some valid generalizations as to "best practice," but also to the development of a much more fruitful and realistic "standard practice."

Refinement of this process of statistical introspection was not long in coming. George A. Works, a nonlibrarian who was chairman of the Division of Education at Cornell University and was later to become dean of the Graduate Library School at the University of Chicago, was retained by the Association of American Universities, again under a Carnegie Corporation grant, to begin the task. His College and University Library Problems, which was issued by ALA in 1927, reported statistical analyses of the libraries in eighteen institutions of higher education, all of which were universities, save for Oberlin and Vassar. The study did not deal at all with internal operational problems, which had been the preoccupation of most literature at that time, but concentrated rather upon identifying relationships between such things as enrollment and collection size, teaching salaries and library expenditures, costs of books and periodicals, salaries of instructors and librarians, and like matters.

The profession's data about itself were further enlarged in 1932 with the publication of somewhat similar statistics and descriptions of more than 200 four-year liberal arts institutions, based upon questionnaires and visits by William M. Randall of the Graduate Library School faculty at the University of Chicago. Entitled The College Li- 
brary, this volume was "primarily a study of conditions. It [was] not in any sense a textbook in college library administration" (p.3). This work was also funded by the Carnegie Corporation and was supervised by its very influential Advisory Group on College Libraries, comprising librarians William Warner Bishop as chairman, Andrew Keogh, Carl Milam, Louis Round Wilson, and a number of college deans and presidents. Among other facts, the study found the ratio of library to institutional expenditure to stand at 9.3 percent, the seating capacity of college library buildings at 25 percent, and the ratio of women to men in the post of head librarians at three to one.

With good reliable data in hand describing practice in academic librarianship, the profession found itself in need of a summary of contemporary thought on the matter. The task of preparing such a summary fell upon Blanche P. McCrum, librarian of Washington and Lee University. Her book, which was somewhat mistitled Estimate of Standards for a College Library, appeared in 1933, having grown out of a document in which she attempted "to summarize for the president and the board of trustees of a college not only the needs of their library, but also the principles behind those needs" (p.ix). McCrum's volume constituted a thorough review of contemporary thought and debate regarding libraries and was drawn not only from the published literature but also extensively from library minutes, annual reports, staff manuals, handbooks, and ephemera.

Armed now with hard data in the volumes by Works and Randall, a summary of theoretical considerations by McCrum, and a growing corpus of relevant papers in the library press, academic librarianship was by the mid-thirties for the first time in a position to produce a true textbook. The task was assumed, naturally enough, by William
M. Randall, who allied himself with F. L. D. Goodrich, librarian of the City College of New York, to produce in 1936 the first edition of their Principles of College Library Administration. Whereas the literature to date had been largely and necessarily descriptive, this textbook was avowedly prescriptive, intending, according to its Preface, "to set forth certain principles which may be applied in the administration of the liberal arts college library" (p.v). The work, which was published by ALA, was widely used and required a second edition in 1941. Fully sixty years after the establishment of its professional association, librarianship at last was possessed of a textbook which it could use in the preparation of aspiring academic librarians.

The balance of the century was one of refining, improving, and broadening textbook coverage of the field. For general college work the quality of available texts was enhanced greatly in 1944 with the appearance of Administration of the College Library by Guy R. Lyle, who was at that time librarian of the University of North Carolina Woman's College. Finding no "suitable textbooks" in the field, Lyle set about to produce a comprehensive work, stressing the "broad view" but emphasizing the "practical" aspects of the work. Its acceptance was immediate, and it promptly superseded its predecessor by Randall and Goodrich as the standard handbook in the field, a recognition which it still enjoys. The work proceeded with little change through a second edition in 1949, a much-revised third edition in 1961, and a fourth revised edition in 1974.

Textbooks on specialties within academic librarianship began shortly thereafter to appear. An exposition of practice in larger, more complex institutions appeared in 1945 under the title The University Library by Louis Round Wilson of the University of North Caro- 
lina and Maurice F. Tauber of Columbia. This book, with its second edition in 1956, served as the standard text on the subject of university library administration until 1971 when a volume with that title appeared written by Yale's Rutherford D. Rogers and Stanford's David C. Weber.

Likewise, smaller academic libraries gained their own texts during the period. A fairly thorough volume on The Junior College Library by Ermine Stone had appeared as early as 1932, and Helen R. Wheeler's Community College Library, a Plan for Action served a useful purpose following its appearance in 1965. The standard textbook in the field, however, had to await the end of the century when Fritz Veit's Community College Library was produced by Greenwood Press in 1975. Meanwhile, a helpful handbook entitled The Small College Library by Sister Helen Sheehan, S.N.D., librarian of Trinity College in the District of Columbia, was issued in 1963, and required a second edition in 1968.

\section{The Evolution of Standards}

The last half-century of academic librarianship has been marked by a dogged search for standards which has been fully as frenetic, as pervasive, and frequently as frustrating and seemingly chimerical as the quest for the Holy Grail. "Standards must exist somewhere, if we are but wise enough and persistent enough to find them," the fiftyyear actions of the profession seem to have implied. Yet a review of those actions also purveys somehow a discomforting sense of unreality, as though academic librarians were, perhaps subconsciously, interested in standards less for purposes of library evaluation than as a manifestation of societal concurrence that what they do is important. Different from the case of the Grail, the pursuit of academic library stan- dards has been at least partially and tentatively successful.

A stated purpose behind the ALA Survey of Libraries in 1926, the Works study in 1927, and the Randall survey in 1932 was to prepare the way for academic library standards. Standards were in each case described to the Carnegie Corporation as a key social benefit that could be expected from the expenditure of its grant money. Standards, it was pointed out, could only be developed out of an understanding of the possible. Carl H. Milam accordingly distilled information from the first two of these three studies and from twenty-six other citations of lesser consequence in the preparation of his "Suggestions for Minimum College Library Standards," which appeared in the second College and Reference Section Yearbook in 1930. The penultimate section of Randall's study two years later noted how the results of his survey could be converted into standards, and he concluded with an actual draft of proposed standards. This draft was offprinted by the sponsoring Advisory Group on College Libraries of the Carnegie Corporation in 1932 and, without benefit of wider approbation, long served as moral suasion for college library development.

The next major spur to action on this knotty problem of college library standards was an effort by the North Central Association of Colleges and Secondary Schools to rationalize its efforts at institutional evaluation for purposes of accreditation. Douglas Waples of the University of Chicago Graduate Library School was retained to study problems of college library evaluation, and the results of his work were published in 1936 with the title The Evaluation of Higher Institutions. IV. The Library. This early effort to determine quantitative standards based upon a description of the status quo recommended that libraries be adjudged on the numbers of books and current journals they held 
that were listed in standard bibliographies, their expenditure for books and journals, the ratio of salary expenditures to enrollment, and the numbers of loans to students and faculty. Waples also noted as unresolved problems such issues as library and institutional excellence, relationships between reading and scholarship, and between reading and extracurricular activities.

The appearance of Waples' study, carrying with it the threat of possible nonaccreditation by the North Central Association, raised a predictable flurry of surrejoinders, notably in the trilogy presented at ALA's midwinter meeting the following year. Published in 1938 in a volume entitled College and University Library Service, edited by A. F. Kuhlman of the Joint University Libraries, these papers were written by Jackson E. Towne of Michigan State University, G. Flint Purdy of Wayne (State) University, and John Dale Russell of the University of Chicago. The Towne and Purdy papers especially expressed the profession's unease that the NCA's standards would evaluate too few of the requisite activities of the college library, that it was limiting them too directly to the curricular offerings of the college, and that the subjective evaluation of quality was unduly subordinated to the objective evaluation of quantity.

The problem of college library standards was hardly solved, but the amount of professional literature devoted to the subject subsided considerably during World War II and the immediate postwar period. Much of the thinking and work on standards for a number of years was done in the regional accrediting associations, generating an understandable apprehension among librarians that they had somehow lost the initiative in their development. Under the editorial oversight of Eli M. Oboler, then of Idaho State College, the ACRL brought together in a volume entitled
College and University Library Accreditation Standards, 1957 all of the requirements for libraries in higher education then being observed by the professional and regional accrediting associations.

In the same year the ACRL Board of Directors authorized and appointed a Committee on Standards chaired by Felix E. Hirsch of Trenton State College. This committee labored for two years and produced in 1959 the first real set of "Standards for College Libraries" to enjoy the consensual support of the profession. This highly influential document was instrumental for some fifteen years thereafter in gaining improvement in college library resources and services not only in America but in the rest of the world as well.

The 1959 standard for which it was most difficult to gain agreement outside the profession was the statement which called for a book collection of 50,000 volumes, augmented by 10,000 additional volumes for each 200 students above 600 . "Why," college presidents and others often asked, "Why 50,000?" And "why should colleges with different purposes all have the same size library?" An epochal effort to improve the plausibility of a quantitative standard for collection size was made in 1965 by Verner W. Clapp and Robert $\mathrm{T}$. Jordan of the Council on Library Resources in a piece unassumingly entitled "Quantitative Criteria for Adequacy of Academic Library Collections." In it they proposed adopting a basic collection size which would then be supplemented in fixed increments for each faculty member, student, and field of concentration in an institution's curriculum. The Clapp/Jordan concept stood up well under subsequent scrutiny and debate and, with certain limited transmogrifications, was adopted for evaluation purposes by several state systems of higher education. A revision of the "Standards for College Libraries," in- 
corporating the Clapp/Jordan concept and other more recent thinking and experience in academic librarianship, was developed in 1975 by an ACRL Committee chaired by Johnnie E. Givens of Austin Peay State University. By the end of the century this document appeared to have received a level of professional approbation similar to that enjoyed by its predecessor.

Junior college libraries experienced somewhat less difficulty developing standards for themselves than had their four-year college brethren. Although Stone had drafted some trial standards in her Junior College Library in 1932, it was not until an ACRL committee, chaired by Felix E. Hirsch, produced a set of "Standards for Junior College Libraries" in 1960 that the profession had a document which it could adopt. These standards served well until they were superseded in 1972 by a set of "Guidelines for Two-Year College Learning Resources Programs." The "Guidelines" were essentially qualitative, and a quantitative supplement to them was authorized by ACRL in 1975. University librarians, on the other hand, found progress on standards more difficult to accomplish. Following years of feckless discussion of the matter, largely within the Association of Research Libraries, the ARL and ACRL joined in 1968 in a somewhat promising effort to devise university library standards. The major research in this direction was made by Robert B. Downs of the University of Illinois in 1969 in his University Library Statistics, which was based upon the premise that the aggregate experience of fifty university libraries noted for their excellence in resources and service ought to provide a foundation upon which standards can be built. As has been seen elsewhere in this review, in other words, it should be possible to move from careful description of what exists to prescription of what should be.

\section{LisTs of BooKs \\ for College Libraries}

It was the same continuing concern for standards that prompted the compilation of the first list of books for college libraries. Unlike the public library field, where the ALA Catalog had been produced in 1904 (and kept current beginning in 1905 by Booklist) simply as a list of recommended titles, the function of the first List of Books for College Libraries was originally conceived as being primarily for collection evaluation and only secondarily for collection development. Thus its first "preliminary" edition in 1930 was viewed by its compiler, Charles B. Shaw, as a holdings list of an ideal college against which an institution could compare itself in different fields. Commissioned by the Carnegie Corporation's Advisory Group on College Libraries, the work listed some 14,200 titles selected upon the recommendation of two hundred college teachers, librarians, and other advisors. The immediate popularity of the work as a buying guide, however, prompted Shaw to alter his views concerning it, and in the second preliminary edition in 1931 he reduced considerably the number of out-of-print titles listed in it in favor of others which were more readily obtainable in the market. A Supplement issued in 1940 listed 3,600 additional titles, all of which were in print.

Although Shaw's lists included periodicals, this was considered to be one of the weaker features of the work, and a special listing of recommended journals seemed to be in order. Building upon work he had done in citation counting as a thesis at Columbia University, Guy R. Lyle, then of Antioch College, produced in 1934 the first edition of his Classified List of Periodicals for the College Library. Through subsequent editions this handlist grew in size and quality and became of considerable 
utility to college librarians. From 376 titles in the first edition, the work expanded to 413 in the second edition in 1938 , to 435 in the third edition in 1948 , to 601 in the fourth edition in 1957 , to 1,048 titles in the fifth edition in 1972 . The last two editions were compiled by Evan I. Farber of Earlham College.

Although certainly never intended for the purpose, the 39,000-entry Catalogue of Harvard's Lamont Library almost immediately superseded Shaw's List as a buying guide for college libraries following its publication in 1953. Its value as a buying guide for other institutions, however, was diminished by its understandable adherence to the vagaries of the Harvard College curriculum which lacked such fields of concentration as business, home economics, education, and agriculture. The rationale for the list was simply expressed in its Introduction by Lamont Librarian Philip J. McNiff as follows: "The books on this list were placed in the Lamont Library only because it was believed they would be used by Harvard undergraduates" (p.vii). Nonetheless, many college librarians, believing apparently that what is good for Harvard must be good for the rest of us, set about attempting to acquire titles on the list which they had not previously held.

A decade later the University of California's New Campuses Program selected some 53,400 titles for its several college libraries, and the list was published by ALA in 1967 as Books for College Libraries. Much more general in its scope than the Lamont Library Catalogue had been, this list served more appropriately as a buying guide for other institutions. Its coverage, moreover, was thereafter kept current by the new periodical Choice, which presented selections of books for general college libraries made with the advice of hundreds of faculty members and librarians in many institutions. Choice grew in the decade following, listing some
3,388 titles in its first year and 6,561 in 1972-73. In 1975 ALA issued the second edition of Books for College Libraries, now a completely generalized list subtitled A Core Collection of 40,000 Titles. . . . This edition, as well as Choice, was made possible through funding from the Council on Library Resources.

Junior colleges have had their booklists as well. In 1931 Edna A. Hester of Pomona College prepared a list of perhaps 4,500 titles for use in the junior colleges of California. Learning of this venture, the ALA published the list as Books for Junior Colleges. A vastly more satisfactory selection, however, was compiled in 1937 by Foster E. Mohrhardt for the Carnegie Corporation's Advisory Group on Junior College Libraries and was published by the ALA with the title List of Books for Junior College Libraries. This entire selection of 5,300 in-print titles was available in the market at the time for $\$ 23,445$, and its 140 periodical titles could be subscribed to at an annual cost of $\$ 618$. The Mohrhardt list was widely used and highly influential in the development of junior college library collections.

Other booklists have also been prepared for lower division institutions. In 1954 Frank J. Bertalan, building from lists submitted by junior college librarians and based upon frequency of nomination, produced his 4,000-title Books for Junior Colleges, which was published by ALA. Among other useful lists have been Basic Books for Junior College Libraries compiled in 1963 by Charles L. Trinkner, and A Basic Book Collection for the Community College Library, produced by Helen R. Wheeler in 1968. The standard guide to collection development in lower division institutions at the end of the century, however, was James W. Pirie's Books for Junior College Libraries, a 19,700title list which was issued by ALA in 1969.

The original purpose for which book- 
lists had been advocated thus had changed completely over the forty-fiveyear period of their existence. Valid though it still sounded in 1976, the "discovery" reported by Randall in 1932, to the effect that "the book collections of a college must contain not a certain number of books, but certain books" (p.133, italics his), had been found difficult to incorporate into library administration. In its place the profession rather had espoused another "discovery," namely that collection quality is easiest to gain at point of input, an apothegm requiring buying guides instead of evaluation lists for implementation.

\section{SERVICES IN Libraries}

Books or seminal articles concerning technical services specifically within academic libraries have been surprisingly few in number. Indeed, virtually no monographs have been prepared on the subject at all, although many of the treatises on technical services in general have been written by academic librarians or have emphasized the academic viewpoint. Thus the first Practical Handbook of Modern Library Cataloging, albeit general in scope, was written in 1914 by William Warner Bishop, then of the Library of Congress, although earlier of Princeton, and destined in the same year to move to Michigan. Margaret Mann was also at Michigan, although as an instructor, when she produced her textbook on Introduction to Cataloging and the Classification of Books in 1930.

Although the present review is supposedly limited to literature concerned specifically with academic libraries, it would be a clear distortion if no mention at all were made of at least the key general works without which academic library collections could never have been organized at all. Melvil Dewey's Classification and Subject Index, prepared at Amherst first in 1876, as well as the Classification Classes of the Library of Congress which began in 1910, would be among such titles. So also would the Anglo-American Code, published in 1908 by ALA as Catalog Rules: Author and Title Entries, and Charles Ammi Cutter's Rules for a Dictionary Catalog, which was influential from its first appearance in 1876 through its more useful fourth edition in 1904 . Both the ALA List of Subject Headings, which appeared first in 1895, and the Library of Congress list of Subject Headings, beginning in 1910, were instrumental in organizing college and university libraries. The full story of the general literature of library technical processing, however, if it is to be told anywhere in this Bicentennial year, must be told elsewhere.

Much the same phenomenon holds true as regards public services in academic libraries; there is little literature here either. In fact, Circulation Work in College and University Libraries, produced in 1933 by Iowa State College's Charles H. Brown and NYU's Humphrey J. Bousfield, may be the only monograph dedicated to public services solely in academic institutions. Again, however, it would be a distortion to ignore here some of the general literature that was written by academic librarians and was influential in the development of public services on campuses. Alice B. Kroeger's Guide to the Study and Use of Reference Books is perhaps the best example. Originally produced at Drex$\mathrm{el}$, this work has for the last sixty-five years come out of Columbia University - under Isadore Gilbert Mudge from 1910, Constance M. Winchell following 1941, and more recently under Eugene P. Sheehy and his associates. Although general in its scope, it has remained a veritable monolith in academic library service. Margaret Hutchins was also at Columbia when she wrote her Introduction to Reference Work in 1944, and William $\mathrm{H}$. Jesse was at the University 
of Tennessee when he produced his Shelf Work in Libraries in 1952.

Public services specifically in academic libraries, however, have benefited greatly over the last two-score years from a body of literature of a very special kind. Partly visionary, partly hortatory, and largely experimental or theoretical, this corpus of writing has concerned the unrealized potential of the college library within the mission of its parent institution. Largely, although not entirely, initiated in the early depression years, these concerns did not produce a heavy literature until shortly before World War II, which event may account in part at least for the fact that it impacted rather slowly on the academic library scene.

A major locus for experimentation along these lines was Stephens College in Missouri. Funded again by the Carnegie Corporation of New York, this junior college for girls appointed an educator from the University of Minnesota, B. Lamar Johnson, to two previously discrete positions now conjoined as dean of instruction and librarian. Johnson was given a tripartite charge: "first, to make the library contribute as effectively as possible to the instructional program of the college; second, to teach students how to use books effectively; and third, to lead students to love books and to read for pleasure." Following a period of learning about libraries, Johnson set about for the subsequent years to accomplish this somewhat awesome charge. He was able, with outside money, to try just about everything anyone could think of that might enhance the value of the library to the Stephens girls, including many things that have subsequently become wrapped into standard college library practice. A key discovery, according to Johnson and reported in his 1939 volume, entitled Vitalizing a College Library, was that "teachers and librarians [should] merge into a single instructional staff" (p.117).

This was not the first time such a notion had appeared in print. The concept had been implicit in Johnson's very appointment to a dual role in 1931, and Ralph Waldo Emerson's concept of "Professorships of Books" had been "in the air" ever since William Mathews and F. B. Perkins of the Boston Public Library had applied it to libraries in their essays in the U.S. Bureau of Education's report on Public Libraries in the United States in 1876. Nonetheless, it somehow seemed more relevant and indeed possible of implementation in the 1930s. In the same vein, Louis Shores of George Peabody College coined the term "Library-Arts College" in a speech at the Chicago Century of Progress Exposition in 1934, and Blanche P. McCrum had recognized its virtue in her Estimate of Standards for a College Library a year earlier.

Although stopping short of recommending actual merger of the instructional and library functions of the college, B. Harvie Branscomb strongly supported the general cause of increasing a library's educational effectiveness in his Teaching with Books in 1940. This book was a report on his work directing "the Library Project" of the Association of American Colleges two years earlier. A professor of early Christian literature at Duke University and former Rhodes Scholar, Branscomb brought his perceptive pedagogical insights and incisive debating skills to his task and produced a volume that was destined probably to accomplish more improvement in American college libraries than any other single document written during the entire century here under review. Finding baldly that "a large percentage of undergraduates ... make such a slight use of the college library that they would scarcely miss it if it ceased to exist" (p.39), he urged closer articulation of the library and the instruc- 
tional program, greater attention to the problem by presidents and deans, improvement in the professional preparation of librarians, and a number of other changes. Coming as it did with the imprimatur of the AAC, although published by ALA, this volume elicited salutary attention and action in many institutions in the land over the subsequent fifteen or more years.

Sensing that many college instructors were inadequately informed about libraries to integrate their resources fully into their teaching, Louis Round Wilson, Mildred Hawksworth Lowell, and Sarah Rebecca Reed produced a volume in 1951 entitled The Library in College Instruction. Discussing general and specific bibliographic sources, the selection of library materials, the value of reading, and the library as a teaching tool, this work attempted to provide a route by which college teachers could aid progress toward the goals set by Branscomb.

A resurgence of interest in the concept of a merged library and instructional capability occurred in the mid1960s. A workshop on the subject at Jamestown College in North Dakota resulted in 1966 in a volume of papers edited by Louis Shores entitled The Library-College. A Library College Journal which commenced publication in 1968 became Learning Today in 1974. By the end of the century, a group called the Library College Associates was also publishing a chonicle of educational events called the Omnibus, a clearinghouse of library-college experience called the Experimenter, and a series of booklets entitled "Learning for Living."

It is sometimes tempting to ask why those enthusiasms of the 1930s never came to fruition, but even to permit the question is to view the last forty-five years of academic librarianship simplistically, because those enthusiasms did bear fruit. When the condition of aca- demic libraries in the 1920 s is scrutinized in comparison with that of the 1970s, it is apparent that much progress has indeed been made, especially in the community colleges, toward the goals promulgated by Shores, Johnson, and Branscomb. The library is more closely integrated with the curriculum today, better instruction in library use is available today, librarians are better prepared as educators today, the library is a more effective educational instrument today, library materials do extend far beyond the codex book today. The fact that so much progress has been made may account, in part at least, for the fact that the library-college movement has no more adherents than it has in the 1970s; progress has been so extensive as to alleviate somewhat the pressure for more.

\section{LIBRARY BUILDINGS}

With library buildings, as has already been noted in several other aspects of library work, there was for a long time little if any literature dealing specifically with academic as distinct from other kinds of libraries. Charles C. Soule's 1912 volume on How to Plan a Library Building for Library Work contained practically no mention of colleges or universities, although many of the precepts he advocated (e.g., "the preeminence of utility over display") were as valid in academe as anywhere. Likewise, Chalmers Hadley's Library Buildings: Notes and Plans in 1924 contained only two pages specifically on academic libraries, being a description, picture, and floor plan of the library at Heidelberg College in Tiffin, Ohio.

Once more it was courtesy of the Carnegie Corporation that the literature of academic library buildings received its start. With its funding, Princeton University librarian James T. Gerould set out in 1931 to visit and report upon the library buildings of fifty academic institutions. Observing that there had 
"been hitherto no handbook of principles and standards by which [colleges] can be guided in the development of a plan "for a new library, Gerould's book, The College Library Building, Its Planning and Equipment, attempted to do just that.

Sounding today like a "period piece," although containing much that is still useful, Gerould's book advocated multitier structural stacks seven feet, six inches deck-to-deck, with reading and service areas fifteen feet floor-to-floor, and it noted that "thirty percent is now almost a minimum" of the enrollment for which seats should be provided (p.29). Gerould promoted browsing rooms and observed that "quite as important as are the books and their setting is the quality of the woman in charge. . . . She should be of ripe culture, human sympathy, and social experience" (p.51-52).

Edna Hanley Byers, librarian of Agnes Scott College, reproduced floor plans, sectional drawings, and elevations, as well as pictures and textual descriptions of forty-two recent libraries in her College and University Buildings, which was published by ALA in 1939. Although general in its coverage, Herman H. Fussler's Library Buildings for Library Service (ALA, 1947) contained essays by four university librarians: William Warner Bishop, Indiana's Robert A. Miller, Colorado's Ralph E. Ellsworth, and William M. Randall. Also, between 1952 and 1956 the proceedings of six ACRL-sponsored building plans institutes were published in the ACRL Monographs series.

The next entire work specifically concerned with academic library buildings, however, was Planning the University Library Building, which had appeared in 1949. This full account reported the "exchange of experience, ideas, and knowledge" (p.viii) that occurred among librarians, faculty members, administrators, and architects in sessions scheduled over five years by the Cooperative Committee on Library Building Plans. It constituted the first comprehensive treatment of the modern modular style of academic library building.

The year 1960 saw the publication of Ralph E. Ellsworth's slender volume on Planning the College and University $\mathrm{Li}$ brary Building. In this highly personal and chatty book, written much in the first person, the author attempted to convey "what I think I know" about the process of effective library building planning. Replete with anecdotes, illustrations, and floor plans, this book continues-now in a 1968 second edition -to serve a useful function in building planning.

This is true despite the publication in 1965 of the comprehensive and definitive book, Planning Academic and Research Library Buildings, by Keyes D. Metcalf, librarian emeritus of Harvard College. This big book, intended to explain academic libraries to architects and architecture to academic librarians, was supported in its preparation by the Council on Library Resources. Its existence has already been of incalculable value in improving the quality of academic library buildings, not only in the United States but in many foreign lands as well; and it appears able to serve for many years to come. It is so thorough and so sound as to render it almost silly to begin planning a library today without first virtually memorizing every word in it.

It fell to Ralph E. Ellsworth, however, to produce one more valuable book on the subject before the century ended. His Academic Library Buildings, also funded by the Council on Library Resources, was issued in 1973. Criticized in some quarters for not being what it was never intended to be-a picture book-this volume did contain pictures, some 1,500 of them. None, however, were chosen for their esthetic or technical quality, and certainly not for their 
beauty; all were selected rather because they demonstrated pictorially how some 130 different recent academic library buildings in North America and Western Europe had resolved certain specific and chronic design problems. It contained minimal text, but the pictures proved invaluable for library planners.

This kind of review of the literature of academic library buildings leads one, foolhardily perhaps, to speculate that the profession may be approaching the end of an era in building design. Just as few really new concepts were incorporated into academic library buildings for three decades following the opening of World War I, so has there been little that is truly innovative in the three decades since World War II. Just as the former period was one of refinement and perfection of the concept of service areas wrapped one-on-two around multitier structural stack cores, so has the latter period been one of finding the best way of utilizing the loft space made available by flexible, modular construction. Some excellent buildings have now been built in both styles-so good, in fact, that substantive improvement in library building quality may now have to await the conceptualization of a whole new revolutionary theory of interaction between library function and structure. It is challenging and tantalizing to ponder just what that might be.

\section{Sertals ...}

Almost two-thirds of the century had passed before academic librarians had their own journal. Although, as was mentioned earlier, such general library periodicals as Library Journal, Public Libraries, the ALA Bulletin, and later the Library Quarterly had published many articles concerned with colleges and universities, the field by 1939 clearly needed a periodical dedicated solely to its own concerns. Accordingly ACRL in that year authorized the establishment of College \& Research Libraries, a periodical intended at once to be its news bulletin, its scholarly journal, and its forum. $C \& R L$ served the first of these three purposes fully until it spawned its separate News in 1966. As a scholarly journal $C \& R L$ 's service began slowly and increased through its lifetime as empirical research in academic librarianship increased in quantity and quality; it tended always to favor papers concerning applied rather than pure research. As a forum for academic librarians, $C \triangleleft R L$ strove to present all sides of any debate or issue facing the profession, although this effort brought upon it some criticism for dissipating its printing space upon articles which were contentious and repetitious. $C \downarrow R L$ 's editors have been the following:
A. F. Kuhlman, 1939-41
Carl M. White, 1941-48
Maurice F. Tauber, 1948-62
Richard B. Harwell, 1962-63
David Kaser, 1963-69
Richard M. Dougherty, 1969-74
Richard D. Johnson, 1974

Academic librarians had had some experience with serial publications of their own prior to the establishment of $C \triangleleft R L$, however. The Yearbook issued annually by ALA's College and Reference Section between 1929 and 1931 had given the field some opportunity to bring together its writings in a single bibliographical location. This publishing effort collapsed certainly because of the depression and perhaps also because of the establishment in 1932 of the Minutes of the Association of Research Libraries. The ARL Minutes expanded rapidly to carry not only committee reports and accounts of its discussions but also the many fine papers, addresses, and reports on university librarianship which were commissioned, or sometimes simply received, by that body. The ARL was also the publisher throughout its life of the Farmington Plan Newsletter 
and of its successor the Foreign Acquisitions Newsletter. In the 1970s ARL's Office of Library Management Studies established two other useful series: its Occasional Papers, concerning such subjects as planning, objectives, and policies; and its SPEC Kits, containing selected documents from its member institutions on such issues as leave policies, collective bargaining, and book selection. ACRL meanwhile developed an extensive serial publishing program of monographic-length writings. Its Monograph series began in 1952 and developed later into its Publications in Librarianship series; its Microcard series, established the following year, became in 1969 its Microform series.

In 1975, noting the growth of the academic library community and anticipating-because of new-found faculty status-increased pressure to publish, Richard M. Dougherty of the University of California established a commercial periodical in the field, the Journal of Academic Librarianship. Its early issues contained articles in many ways similar to those that had appeared during the previous decade in $C \& R L$, which Dougherty had edited for five years. It also began publishing an attractive new feature containing excerpts from published reviews of recent books in the field.

\section{... AND SURVEYS}

No review of the literature of academic libraries would be complete without observing the great historical importance of library surveys. Their utility and influence have been thoroughly examined and reported in College and University Library Surveys by Eastern Michigan University's E. Walfred Erickson and need not be discussed here in extenso. Nonetheless, the enormous value of the monuments among them as instruments of organizational development dictates their notice in this essay. Coming, as many of them did, at a time before there were either textbooks or an extensive open research literature, they pitted the wide proprietary knowledge borne of extensive experienceand often the sagacity and wisdom-of their authors against many of the peskiest problems of the profession.

Several kinds of library surveys have left their mark upon academic librarianship: self-surveys, surveys by accrediting agencies, others by management consultants, and studies by teams of experts from within the library profession. All four kinds have been useful. By far the most important survey literature, however, was that produced by teams of library experts, primarily between the late 1930s and the early 1950s. Since most of these surveys were published over the imprint of ALA, they were widely read, and their impact extended far beyond the specific institutions which they examined.

Louis Round Wilson, as would be expected, was involved in many of these surveys. He and several colleagues studied and reported upon the University of Georgia Library in 1939; with Guy R. Lyle and A. F. Kuhlman, he surveyed the University of Florida Library in 1940; together with Robert B. Downs and Maurice F. Tauber, he studied the Cornell University Libraries in 1948; and he and Frank A. Lundy of the University of Nebraska surveyed Notre Dame in 1952. The University of Texas' Donald Coney, Herman H. Henkle of Simmons College, and G. Flint Purdy conducted a library survey at Indiana University; and Tauber and Colorado's E. H. Wilson examined Montana State University in 1951. More recently, Columbia University Libraries benefited from one self-survey under the auspices of the University President's Committee on the Educational Future of the University, which in 1958 defined many of the future needs of the Columbia University Libraries; and another effort in 1973 conducted jointly by the staff and 
the management firm of Booz Allen \& Hamilton proposed new patterns for the Organization and Staffing of the Libraries of Columbia University. These and many others have had a wide influence.

One can only speculate as to the reasons for the decline in the importance of surveys during the last quarter-century. It is probable that the increasing professionalization of academic librarianship has gained improved credibility for the resident library staff, thereby reducing reliance upon experts from outside the institution. Certainly the methods used by outside surveyors have become more widely known and have, therefore, been susceptible to copy by institutions that would survey themselves. Perhaps also, what one might call the "democratization of knowledge" about the profession-the more widespread teaching of theory and principle in the library schools as distinct from technique-may have enabled operating librarians to resolve more of their own problems rather than relying upon outside experts. Maybe, in other words, experts, like heroes, no longer exist. Certainly, however, experts, like heroes, have left their mark upon our past, and the literature of library surveys was a prime carrier for their influence.

\section{Conclusions}

Several impressions can be drawn from this cursory review of some of the more important pieces of literature on academic librarianship. Preeminent among them perhaps is that there is little that is ever truly new in the field. Cooperation, status, evaluation, concern for service, and virtually all other motivating issues have been around for a long time. The profession seems often to forget from one generation to the next that it has faced these issues before, and as a result it often attacks them repeatedly in exactly the same way, sometimes even making the same errors over again.

Another impression that is gained from such a survey is that a very small segment of the profession at any given moment is the fountainhead of a very large share of the writing in the field. This impression would seem to be subject to proof or disproof by objective analysis and would seem to deserve being done, although problems would exist if one attempted also to gauge the value or influence of that writing. Related to this impression is another that the American Library Association has been the publisher of a very high percentage of the landmark literature of academic librarianship over the century of its existence.

Finally, an interesting cycle seems to emerge through which the literature of the profession grows and develops. First in evidence are very simple descriptive statements of conditions and operations within single institutions. Several such descriptions permit trial generalizations to be made in subsequent writings. These are later tested against broad surveys of experience in many libraries. Thus far, all has been descriptive, but now prescriptive statements can for the first time with some authority be made. Subsequent literature refines the prescriptions until consensus is attained. With consensus come standards, and once tenable standards can be agreed upon and with some success enforced, a profession has attained maturity. A review of the past century of academic librarianship as reflected in its literature suggests that the profession is now at that point in its development.

\section{BIBLIOGRAPHY}

American Library Association. Catalog of the "A.L.A." Library. Washington, D.C.: U.S. Govt. Print. Off., 1893.
American Library Association. College and Reference Library Yearbook. Chicago: American Library Assn., 1929-31. 
American Library Association. List of Subject Headings for Use in Dictionary Catalogs. Boston: Library Bureau, 1895. . 2 d ed. 1905. 3d ed. 1911.

American Library Association. Survey of Libraries in the United States. 4 vol. Chicago: American Library Assn., 1926.

Association of College and Research Libraries. Books for College Libraries. . . . Chicago: American Library Assn., 1967.

—. 2 d ed. 1975.

Association of College and Research Libraries. Microform Series. Chicago: 1952-

Association of College and Research Libraries. Publications in Librarianship. Chicago: 1952

Association of Research Libraries. Minutes. Washington, D.C.: 1932

Association of Research Libraries. Office of Library Management Studies. Occasional $\mathrm{Pa}$ pers. Washington, D.C.: 1971-

Association of Research Libraries. Office of Library Management Studies. SPEC Kits. Washington, D.C.: 1974

Bibliography of American Library Administration, 1899-1926. Albany: New York State Library, 1926.

Bishop, William W. Practical Handbook of Modern Library Cataloging. Baltimore: Williams \& Wilkins, 1914.

Booklist and Subscription Books Bulletin. Chicago: American Library Assn., 1905-

Booz, Allen \& Hamilton, Inc. Organization and Staffing of the Libraries of Columbia University. Westport, Conn.: Redgrave Information Sources, 1973.

Branscomb, B. Harvie, Teaching with Books. Chicago: American Library Assn., 1940.

Brown, Charles H., and Bousfield, H. G. Circulation Work in College and University Libraries. Chicago: American Library Assn., 1933.

Burchard, John E., and others. Planning the University Library Building. Princeton, N.J.: Princeton Univ. Pr., 1949.

Byers, Edna Hanley. College and University Library Buildings. Chicago: American Library Assn., 1939.

Carnegie Corporation of New York Advisory Group on College Libraries. College Library Standards. New York: Carnegie Corp., 1932.

Choice, vol. 1-. 1964

College \& Research Libraries. vol, 1-. 1939

Columbia University. President's Committee on the Educational Future of the University. Subcommittee on the University Libraries. The Columbia University Libraries. New York: Columbia Univ. Pr., 1958.

Cutter, Charles A. Rules for a Printed Dic- tionary Catalogue. Washington, D.C.: U.S. Govt. Print. Off., 1876. . $2 \mathrm{~d}$ ed. 1889. 3d ed. 1891. 4th ed. 1904.

Dewey, Melvil. A Classification and Subject Index for Cataloguing and Arranging the Books and Pamphlets of a Library. Amherst, Mass.: 1876.

Downs, Robert B. University Library Statistics. Washington, D.C.: Association of Research Libraries, 1969.

Ellsworth, Ralph E. Academic Library Buildings. Boulder, Colo.: Colorado Associated Univ. Pr., 1973.

Ellsworth, Ralph E. Planning the College and University Library Building. Boulder, Colo.: Pruett Press, 1960. 1968.

Erickson, E. Walfred. College and University Library Surveys, 1938-1952. Chicago: American Library Assn., 1961.

Farber, Evan I. Classified List of Periodicals for the College Library. 4th ed. Boston: Faxon, 1957.

. 5th ed. 1972.

Fussler, Herman H., ed. Library Buildings for Library Service. Chicago: American Library Assn., 1947.

Gerould, James T. The College Library Building, Its Planning and Equipment. New York: Scribner, 1932.

"Guidelines for Two-Year College Learning Resources Programs," College \& Research Libraries News 33:305-15 (Dec. 1972).

Hadley, Chalmers. Library Buildings: Notes and Plans. Chicago: American Library Assn., 1924.

Harvard University Library. Lamont Library. Catalogue. Cambridge, Mass.: Harvard Univ. Pr., 1953.

Hester, Edna A. Books for Junior Colleges. Chicago: American Library Assn., 1931.

Hutchins, Margaret. Introduction to Reference Work. Chicago: American Library Assn., 1944.

Johnson, B. Lamar. Vitalizing a College Library. Chicago: American Library Assn., 1939.

Jesse, William H. Shelf Work in Libraries. Chicago: American Library Assn., 1952.

Journal of Academic Librarianship. vol. 1-. 1975-

Kroeger, Alice B. Guide to the Study and Use of Reference Books. Boston: American Library Assn., 1902.

. 2 d ed. 1908.

Kuhlman, A. F., ed. College and University Service; Trends, Standards, Appraisal, Problems. Chicago: American Library Assn., 
1938.

Learning Today. 1968-

Libraries. 1896-1931.

Library Journal. 1876-

Lyle, Guy R. Administration of the College Library. New York: Wilson, 1944.

2d ed. 1949.

3d ed. 1961.

4th ed. 1974.

Lyle, Guy R. Classified List of Periodicals for the College Library. Boston: Faxon, 1934. 2d ed. 1938.

3d ed. 1948; (4th and 5th eds., see Farber, Evan I.)

McCrum, Blanche P. Estimate of Standards for a College Library. Lexington, Va.: Washington and Lee Univ. Pr., 1933. 2 d ed. 1937.

Metcalf, Keyes D. Planning Academic and Research Library Buildings. New York: McGraw-Hill, 1965.

Mohrhardt, Foster E., comp. List of Books for Junior College Libraries. Chicago: American Library Assn., 1937.

Mudge, Isadore Gilbert. Guide to Reference Books. 3d ed. Chicago: American Library Assn., 1917.

. 4th ed. 1923.

. 5th ed. 1929.

6th ed. 1936.

Oboler, Eli M., ed. College and University Library Accreditation Standards. Chicago: American Library Assn., 1958.

Pirie, James W. Books for Junior College Libraries. Chicago: American Library Assn., 1969.

Randall, William M. The College Library. Chicago: Univ. of Chicago Pr., 1932.

Randall, William M., and Goodrich, F. L. D. Principles of College Library Administration. Chicago: American Library Assn., 1936.

. 2 d ed. 1941.

Rogers, Rutherford D., and Weber, D. University Library Administration. New York: Wilson, 1971.

Shaw, Charles B., comp. List of Books for College Libraries. 1st prelim. ed. New York: Carnegie Corp., 1930.

. $2 \mathrm{~d}$ prelim. ed. Chicago: American Library Assn., 1931.

- Supplement, 1940.

Sheehan, Sister Helen. The Small College Library. Westminster, Md.: Newman Press, 1963.

Rev. ed. Washington, D.C.: Corpus Books, 1968.
Shores, Louis, ed. Library-College. Philadelphia: Drexel Univ. Pr., 1966.

Soule, Charles C. How to Plan a Library Building for Library Work. Boston: Boston Book Co., 1912.

"Standards for College Libraries," College \& Research Libraries 20:274-80 (July 1959).

"Standards for College Libraries," College d Research Libraries News 36:277-79 (Oct. 1975).

"Standards for Junior College Libraries," College \& Research Libraries 21:200-206 (May $1960)$.

Stone, Ermine. The Junior College Library. Chicago: American Library Assn., 1932.

U.S. Bureau of Education. Public Libraries in the United States. Washington, D.C., 1876.

U.S. Library of Congress. Catalog Division. Subject Headings Used in the Dictionary Catalogues. Washington, D.C.: U.S. Govt. Print. Off., 1910.

U.S. Library of Congress. Classification Division. Classification Classes A-Z. Washington, D.C.: U.S. Govt. Print. Off., 1910.

Waples, Douglas. The Evaluation of Higher Institutions. IV. The Library. Chicago: Univ. of Chicago Pr., 1936.

Wheeler, Helen R. Basic Book Collection for the Community College Library. Hamden, Conn.: Shoe String, 1968.

Wheeler, Helen R. The Community College Library, A Plan for Action. Hamden, Conn.: Shoe String, 1965.

Williams, Hugh. College Libraries in the United States; ... A Bibliography. Albany: New York State Library, 1899.

Wilson, Louis R., and others. The Library in College Instruction. New York: Wilson, 1951.

Wilson, Louis R., and Tauber, M. The University Library. Chicago: Univ. of Chicago Pr., 1945.

2d ed. New York: Columbia Univ. Pr., 1956.

Winchell, Constance M. Guide to Reference Books. 7th ed. Chicago: American Library Assn., 1951.

. 8th ed. 1967.

Works, George A. College and University Library Problems. Chicago: American Library Assn., 1927.

Wyer, James Ingersoll. The College and University Library. Chicago: American Library Assn., 1911.

— 2 d ed. 1921.

. 3d ed. 1928.

David Kaser, a former editor of

College \& Research Libraries, is professor

in the Graduate Library School

of Indiana University. 